Pacific Journal of Mathematic 


\title{
THE CENTER OF A COMPACT LATTICE \\ IS TOTALLY DISCONNECTED
}

\author{
Alexander Doniphan Wallace
}

The purpose of this note is to prove the theorem of the title. A topological lattice is a Hausdorff space together with a pair of continuous functions $\wedge: L \times L \rightarrow L, \vee: L \times L \rightarrow L$ satisfying the usual conditions for lattice operations. As is customary we may write $x \wedge y$ in place of $\wedge(x, y)$. All references are to Chapter II of [1]. We assume the reader to be familiar with the elementary facts concerning topological algebras (groups, lattices, semigroups) and set-theoretic topology.

\section{THEOREM. The center of a compact lattice is totally disconnected.}

Proof. Let $L$ be a compact lattice. As is wellknown $L$ has a zero and a unit, 0 and 1. If $A$ is the set of pairs $(x, y) \in L \times L$ such that $x \wedge y=0$ and $x \vee y=1$ then $A=\wedge^{-1}(0) \cap \vee^{-1}(1)$ so that $A$ is closed. The projection $(x, y) \rightarrow x$ takes $A$ onto the closed set $B$ and $B$ is the set of all $x \in L$ which admit a complement.

Now $N$, the set of neutral elements of $L$, is the intersection of the maximal distributive sublattices by Theorem 11 . But if $D$ is a distributive sublattice of $L$ its closure is also a distributive sublattice. It follows that $N$ is closed. By the corollary to Theorem 10 the center $C$ of $L$ is $N \cap B$ so that $C$ is closed.

By the lemma on page 27 each element $x \in C$ has a unique complement $k(x) \in C$. We will show that $k: C \rightarrow C$ is continuous. If $G$ is the subset of $C \times C$ consisting of all $(x, k(x))$ with $x \in C$ it is enough to show that $G$ is closed since $C$ is compact. But by the remarks above we have $G=(C \times C) \cap \wedge^{-1}(0) \cap \bigvee^{-1}(1)$.

Now $C$ is a distributive lattice (Theorem 9 and Corollary p. 29) with unique complements. Thus $C$ is a commutative topological group under the operations

$$
x+y=(x \wedge k(y)) \vee(k(x) \wedge y), \quad-x=x
$$

all of whose elements are of order 2 , that is, $x+x=0$ for all $x$. If $Q$ is the component of $C$ containing 0 and if $q \in Q, q \neq 0$, then there is a continuous homomorphism $f$ taking $Q$ into $Z$, the reals mod 1 , such that $f(q) \neq f(0)$. Since $f(Q)$ is connected it contains an interval of $Z$ and therefore contains an element not of finite order. Since the order of each element of $Q$ is two this is a contradiction. Hence $Q$ contains

Received August_6, 1956. 
only 0 and therefore is totally disconnected. The proof of the Theorem is complete.

\section{REFERENCE}

1. G. Birkhoff, Lattice theory, New York, 1948.

The Tulane University of Louisiana 


\section{PACIFIC JOURNAL OF MATHEMATICS}

\section{EDITORS}

H. L. ROYDEN

Stanford University

Stanford, California

R. A. Beaumont

University of Washington

Seattle 5, Washington

\section{A. L. Whiteman}

University of Southern California

Los Angeles 7, California

E. G. Straus

University of California

Los Angeles 24, California

\section{ASSOCIATE EDITORS}
E. F. BECKENBACH
C. E. BURGESS
M. HALL
E. HEWITT

\author{
A. HORN \\ V. GANAPATHY IYER \\ R. D. JAMES \\ M. S. KNEBELMAN
}

L. NACHBIN

I. NIVEN

G. SZEKERES

T. G. OSTROM

M. M. SCHIFFER
F. WOLF

K. YOSIDA

\section{SUPPORTING INSTITUTIONS}

\author{
UNIVERSITY OF BRITISH COLUMBIA \\ CALIFORNIA INSTITUTE OF TECHNOLOGY \\ UNIVERSITY OF CALIFORNIA \\ MONTANA STATE UNIVERSITY \\ UNIVERSITY OF NEVADA \\ OREGON STATE COLLEGE \\ UNIVERSITY OF OREGON \\ UNIVERSITY OF SOUTHERN CALIFORNIA
}

\author{
STANFORD UNIVERSITY \\ UNIVERSITY OF UTAH \\ WASHINGTON STATE COLLEGE \\ UNIVERSITY OF WASHINGTON \\ AMERICAN MATHEMATICAL SOCIETY \\ CALIFORNIA RESEARCH CORPORATION \\ HUGHES AIRCRAFT COMPANY \\ THE RAMO-WOOLDRIDGE CORPORATION
}

Mathematical papers intended for publication in the Pacific Journal of Mathematics should be typewritten (double spaced), and the author should keep a complete copy. Manuscripts may be sent to any of the editors. All other communications to the editors should be addressed to the managing editor, E. G. Straus at the University of California, Los Angeles 24, California.

50 reprints per author of each article are furnished free of charge; additional copies may be obtained at cost in multiples of 50 .

The Pacific Journal, of Mathematics is published quarterly, in March, June, September, and December. The price per volume (4 numbers) is $\$ 12.00$; single issues, $\$ 3.50$. Back numbers are available. Special price to individual faculty members of supporting institutions and to individual members of the American Mathematical Society: $\$ 4.00$ per volume; single issues, $\$ 1.25$.

Subscriptions, orders for back numbers, and changes of address should be sent to Pacific Journal of Mathematics, 2120 Oxford Street, Berkeley 4, California.

Printed at Kokusai Bunken Insatsusha (International Academic Printing Co., Ltd.), No. 10, 1-chome, Fujimi-cho, Chiyoda-ku, Tokyo, Japan.

PUBLISHED BY PACIFIC JOURNAL OF MATHEMATICS, A NON-PROFIT CORPORATION

The Supporting Institutions listed above contribute to the cost of publication of this Journal, but they are not owners or publishers and have no responsibility for its content or policies. 


\section{Pacific Journal of Mathematics}

\section{Vol. 7, No. 2 \\ February, 1957}

William F. Donoghue, Jr., The lattice of invariant subspaces of a completely continuous quasi-nilpotent transformation ................... 1031

Michael (Mihály) Fekete and J. L. Walsh, Asymptotic behavior of restricted extremal polynomials and of their zeros.................... 1037

Shaul Foguel, Biorthogonal systems in Banach spaces ............... 1065

David Gale, A theorem on flows in networks ................... 1073

Ioan M. James, On spaces with a multiplication .................. 1083

Richard Vincent Kadison and Isadore Manual Singer, Three test problems in operator theory .................................... 1101

Maurice Kennedy, A convergence theorem for a certain class of Markoff processes........................................ 1107

G. Kurepa, On a new reciprocity, distribution and duality law ........ 1125

Richard Kenneth Lashof, Lie algebras of locally compact groups ........ 1145

Calvin T. Long, Note on normal numbers .................... 1163

M. Mikolás, On certain sums generating the Dedekind sums and their reciprocity laws ..................................... 1167

Barrett O'Neill, Induced homology homomorphisms for set-valued maps......................................... 1179

Mary Ellen Rudin, A topological characterization of sets of real numbers........................................... 1185

M. Schiffer, The Fredholm eigen values of plane domains 1187

F. A. Valentine, A three point convexity property .........

Alexander Doniphan Wallace, The center of a compact lattice is totally

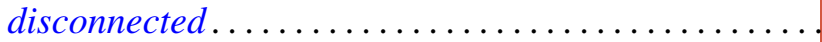

Alexander Doniphan Wallace, Two theorems on topological lattices.

G. T. Whyburn, Dimension and non-density preservation of mappings...

John Hunter Williamson, On the functional representation of certain algebraic systems ... 